\title{
Purification and Properties of NADP+-linked Glycerol Dehydrogenase from Neurospora crassa
}

\author{
By M. VISWANATH-REDDY, JOSEPH E. PYLE AND \\ H. BRANCH HOWE, JR \\ Department of Microbiology, University of Georgia, Athens, Georgia 30602, U.S.A.
}

(Received 21 February 1978)

\begin{abstract}
The properties of NADP+-linked glycerol dehydrogenase (EC 1.1.1.72) from Neurospora crassa were studied following 505 -fold purification, with $54 \%$ yield, by gel filtration, ion exchange chromatography and affinity chromatography. Specific staining for the purified enzyme after disc gel electrophoresis revealed a single band and after isoelectric focusing, five bands. No enzymically inactive bands were detected by general protein staining in control gels. Total molecular weight was estimated to be about 160000 , with a subunit molecular weight of about 43000 . The forward reaction from glycerol to D-glyceraldehyde had a $\mathrm{pH}$ optimum of $\mathbf{9 . 5}$ and was specific for glycerol as substrate, since no activity was detected with other polyols tested. The reverse reaction had a $\mathrm{pH}$ optimum of 6.5 and was maximal with D-glyceraldehyde as substrate. $K_{\mathrm{m}}$ values for glycerol and D-glyceraldehyde were $1.43 \times 10^{-1} \mathrm{M}$ and $1.15 \times 10^{-2} \mathrm{M}$, respectively. Dihydroxyacetone also served as substrate in the reverse reaction. The enzyme was $\mathrm{NADP}^{+}$-specific.
\end{abstract}

\section{INTRODUCTION}

Two oxidative pathways are known to be involved in the dissimilation of glycerol in various organisms. In one pathway, glycerol is oxidized to dihydroxyacetone by an NAD ${ }^{+}$ linked glycerol dehydrogenase. In the other pathway, glycerol is oxidized to glyceraldehyde by an NADP+-linked glycerol dehydrogenase. During a previous study, we detected NADP $^{+}$-linked glycerol dehydrogenase in wild-type strains of Neurospora, whereas the NAD+-linked enzyme was apparently absent (Viswanath-Reddy et al., 1977). NAD+-linked glycerol dehydrogenase has been reported mostly in prokaryotes (Lin, 1976).

Two types of NADP+-linked glycerol dehydrogenase have been described. First, a relatively substrate-specific type which reversibly catalyses the conversion of glycerol to glyceraldehyde (Toews, 1966, 1967; Sheys et al., 1971; Kormann et al., 1972) or to dihydroxyacetone (Ben-Amotz \& Avron, 1973; Dutler et al., 1977; Hochuli et al., 1977), and secondly, a non-specific type called aldehyde reductase which not only catalyses the reduction of aldoses such as glyceraldehyde but also oxidizes several sugar alcohols (polyols) such as D-sorbitol, L-arabitol and glycerol (Bosron \& Prairie, 1972). We have detected high levels of $\mathrm{NADP}^{+}$-linked polyol dehydrogenase activity with sorbitol, mannitol, xylitol and glycerol in crude extracts of Neurospora crassa. The purpose of the present study was to determine the nature of NADP+-linked glycerol dehydrogenase activity in $N$. crassa. We report here a purification procedure for $\mathrm{NADP}^{+}$-linked glycerol dehydrogenase and describe some of the properties of this enzyme; we found it to be a relatively substrate-specific type and distinct from polyol dehydrogenase. 


\section{METHODS}

Organism. Neurospora crassa wild-type strain 74-OR23-1A, from the Fungal Genetics Stock Centre, Arcata, California, U.S.A., was used.

Chemicals. Sodium dodecyl sulphate (SDS) was obtained from Matheson Coleman and Bell, East Rutherford, New Jersey, U.S.A.; DEAE Bio-Gel A, Bio-Lyte 3/10 ampholytes and acrylamide from Bio-Rad Laboratories, Richmond, California, U.S.A.; Good's buffers from U.S. Biochemical Corp., Cleveland, Ohio, U.S.A.; chymotrypsinogen, ovalbumin and ribonuclease A from Isolab, Akron, Ohio, U.S.A.; enzyme grade ammonium sulphate and riboflavin- $5^{\prime}$-phosphate from ICN Nutritional Biochemicals Corp., Cleveland, Ohio, U.S.A.; Sephadex G-100 and G-200 from Pharmacia; and Cibacron Blue F3GA from CibaGeigy. Other biochemical reagents, of the highest purity available, were obtained from Sigma. Inorganic chemicals were obtained from Fisher Scientific Co., Fairlawn, New Jersey, U.S.A.

Culture conditions and preparation of crude enzyme extract. The fungus was grown at $25^{\circ} \mathrm{C}$ for $36 \mathrm{~h}$ in 101 Westergaard \& Mitchell medium (1947) in 141 carboys. Carboys were inoculated at a final concentration of $10^{6}$ conidia $\mathrm{ml}^{-1}$ and sparged with sterile air. Mycelia were harvested by filtration through cheesecloth on a Buchner funnel, washed thoroughly with cold distilled water, dried between paper towels and weighed. Mycelial weights averaged $85 \mathrm{~g}$ per carboy.

The temperature was maintained at 0 to $4{ }^{\circ} \mathrm{C}$ throughout the purification procedure. Mycelia $(100 \mathrm{~g})$ were cut into small pieces and suspended in 2 vol. cold $0.1 \mathrm{M}-\mathrm{Tris} / \mathrm{HCl}$ buffer (pH 7.4), containing $0.5 \mathrm{~mm}-2$ mercaptoethanol and $100 \mathrm{~g}$ glass beads $(0.5 \mathrm{~mm}$ diameter). The mixture was homogenized intermittently in a Virtis homogenizer up to a setting of 90 for $30 \mathrm{~min}$. The homogenate was centrifuged at $1500 \mathrm{~g}$ for $15 \mathrm{~min}$ in a Sorvall refrigerated centrifuge to remove glass beads and debris, and the supernatant was centrifuged at $20000 \mathrm{~g}$ for $30 \mathrm{~min}$. The supernatant from the second centrifugation constituted the crude enzyme extract.

Enzyme assay. Glycerol dehydrogenase (glycerol:NADP ${ }^{+}$oxidoreductase; EC 1.1.1.72) activity was assayed by following the change in absorbance of pyridine nucleotide at $340 \mathrm{~nm}$ in cuvettes of $1 \mathrm{~cm}$ light path in an Hitachi Perkin-Elmer 139 UV-VIS spectrophotometer equipped with a Sargent model SRLG recorder.

The forward reaction i.e. glycerol oxidation to D-glyceraldehyde, was used to determine enzyme activity throughout the purification procedure.

$$
\text { Glycerol + NADP }+\underset{\text { dehydrogenase }}{\stackrel{\text { Glycerol }}{\longleftrightarrow}} \text { D-glyceraldehyde }+\mathrm{NADPH}+\mathrm{H}^{+}
$$

The forward reaction mixture contained 50 mM-sodium bicarbonate buffer (pH 10), 0.25 mM-NADP ${ }^{+}$, $100 \mathrm{~mm}$-glycerol, 5 to $10 \mu \mathrm{l}$ enzyme extract (as required) and distilled water to $2 \mathrm{ml}$ final volume. The reaction was initiated by the addition of NADP+ and was linear up to $5 \mathrm{~min}$.

The reverse reaction mixture contained $50 \mathrm{~mm}-2-(N$-morpholino)ethanesulphonic acid (MES) buffer (pH 6.5), $0.25 \mathrm{~mm}-\mathrm{NADPH}, 50 \mathrm{mM}-\mathrm{D}$-glyceraldehyde, 5 to $10 \mu \mathrm{l}$ enzyme extract (as required) and distilled water to $2 \mathrm{ml}$ final volume. The reaction was initiated by the addition of NADPH and was linear up to $3 \mathrm{~min}$.

One unit of enzyme activity was defined as that amount of activity which catalysed the formation of $1 \mu \mathrm{mol} \mathrm{NADP}{ }^{+}$or NADPH per min at $25^{\circ} \mathrm{C}$. An absorption coefficient of $6.22 \times 10^{3} 1 \mathrm{~mol}^{-1} \mathrm{~cm}^{-1}$ at $340 \mathrm{~nm}$ was used to calculate the amount of coenzyme. The specific activity was expressed as enzyme units (mg protein $)^{-1}$. Biuret and Lowry protein determinations were performed according to procedures outlined by Bergmeyer (1974).

Michaelis-Menten constants were determined from Lineweaver-Burk plots, with limiting substrate or cofactor added in appropriate amounts. The pH optima of the enzyme were determined by substitution of the appropriate Good's buffer (Good et al., 1966) in the reaction mixture. The buffers used were 0.1 M-CAPS (pH 10 to 11), $0 \cdot 1 \mathrm{M}$-CHES (pH 9 to $9 \cdot 5$ ) $0 \cdot 1 \mathrm{M}$-HEPPS (pH 8.5), $0 \cdot 1 \mathrm{M}$-HEPES (pH 7 to 8), $0 \cdot 1 \mathrm{M}-\mathrm{MOPS}$ (pH 6.5 to 7 ) and $0.1 \mathrm{M}-\mathrm{MES}(\mathrm{pH} 5.5$ to 6.5 ).

Preparation of Cibacron Blue-Sepharose and calcium phosphate gel. Cibacron Blue was attached to Sepharose 4B-200 by a slightly modified method of Böhme et al. (1972). Sepharose 4B-200 (200 ml) was suspended in $200 \mathrm{ml}$ distilled water in a $60^{\circ} \mathrm{C}$ water bath, and the dye solution $(2 \mathrm{~g}$ Cibacron Blue in $60 \mathrm{ml}$ distilled water) was added dropwise with gentle stirring. After addition of the dye, stirring was continued for $15 \mathrm{~min}, 45 \mathrm{~g} \mathrm{NaCl}$ was added and the mixture was stirred for a further $30 \mathrm{~min}$. The mixture was then heated to $70{ }^{\circ} \mathrm{C}$, treated with $4 \mathrm{~g} \mathrm{Na}_{2} \mathrm{CO}_{3}$ and stirring was continued for another $1.5 \mathrm{~h}$. The mixture was allowed to cool to room temperature and the unreacted dye was removed by filtration, with repeated washing of the gel with distilled water until the filtrate became colourless. Calcium phosphate gel was prepared according to the method of Keilin \& Hartree (1938). The gel was stored at $4{ }^{\circ} \mathrm{C}$ at least 1 month before use.

Polyacrylamide disc gel electrophoresis. Disc gel electrophoresis was performed in $7.5 \%(\mathrm{w} / \mathrm{v})$ polyacrylamide gels with $0.1 \mathrm{M}$-Tris/glycine buffer $(\mathrm{pH} 8.9)$ in $5 \times 75 \mathrm{~mm}$ glass tubes, according to the procedure of Davis (1964). The samples were run at $2.5 \mathrm{~mA}$ per gel at $4{ }^{\circ} \mathrm{C}$. Gels were stained for protein in three steps: 
Table 1. Purification of $N A D P^{+-l i n k e d ~ g l y c e r o l ~ d e h y d r o g e n a s e ~ f r o m ~ N e u r o s p o r a ~ c r a s s a ~}$

\begin{tabular}{lcccccc}
\multicolumn{1}{c}{ Fraction } & $\begin{array}{c}\text { Volume } \\
(\mathrm{ml})\end{array}$ & $\begin{array}{c}\text { Protein } \\
(\mathrm{mg})\end{array}$ & $\begin{array}{c}\text { Activity } \\
\text { (units) }\end{array}$ & $\begin{array}{c}\text { Specific } \\
\text { activity }\end{array}$ & $\begin{array}{c}\text { Yield } \\
(\%)\end{array}$ & $\begin{array}{c}\text { Purification } \\
\text { factor }\end{array}$ \\
Crude extract & 952 & 9900 & 405 & 0.041 & 100 & \\
Ethodin & 983 & 3846 & 406 & $\mathbf{0 . 1 0 6}$ & 100 & $2 \cdot 6$ \\
Ammonium sulphate & 100 & 1357 & 328 & $0 \cdot 242$ & 81 & $5 \cdot 9$ \\
Calcium phosphate & 20 & 1021 & 297 & $0 \cdot 291$ & 73 & $7 \cdot 1$ \\
Sephadex G-100 & 20 & 564 & 292 & $0 \cdot 518$ & 72 & $12 \cdot 6$ \\
DEAE Bio-Gel A & 20 & 147 & 266 & $1 \cdot 81$ & 66 & 44 \\
Cibacron Blue & 14 & $10 \cdot 5$ & 218 & $20 \cdot 7$ & 54 & 505
\end{tabular}

(i) fixation overnight in a solution containing $0.5 \mathrm{~g} \mathrm{CuSO}_{4}, 0.05 \mathrm{~g}$ Coomassie Brilliant Blue $\mathrm{R}, 10 \mathrm{ml}$ acetic acid, $27 \mathrm{ml}$ absolute ethanol and distilled water to $100 \mathrm{ml}$; (ii) fixation for $6 \mathrm{~h}$ in a solution containing $0.01 \mathrm{~g}$ Coomassie Brilliant Blue R, $10 \mathrm{ml}$ acetic acid, $25 \mathrm{ml}$ absolute ethanol and distilled water to $100 \mathrm{ml}$; and (iii) destaining in a solution containing $10 \mathrm{ml}$ acetic acid, $10 \mathrm{ml}$ absolute ethanol and distilled water to $100 \mathrm{ml}$. Gels were stained specifically for glycerol dehydrogenase as follows. The staining mixture consisted of $10 \mathrm{ml}$ $0 \cdot 1 \mathrm{M}$-sodium bicarbonate buffer (pH 10), $4 \mathrm{mg} \mathrm{3-(4,5-dimethylthiazolyl-2)-2,5-diphenyl} \mathrm{monotetrazolium}$ bromide (MTT), $400 \mu \mathrm{g}$ phenazine methosulphate, $6 \mathrm{mg} \mathrm{NADP}+, 2 \mathrm{ml} 1 \mathrm{M}$-glycerol and $8 \mathrm{ml}$ distilled water. The gels were incubated in the staining solution at $37^{\circ} \mathrm{C}$ until adequately stained, usually 20 to $30 \mathrm{~min}$. Control gels stained with this mixture without glycerol showed no bands.

Isoelectric focusing in polyacrylamide gels. Isoelectric focusing was performed in $7.5 \%$ polyacrylamide gels containing Bio-Lyte ampholytes ( $1 \%$ w/v; pH range 3 to 10$)$ in $5 \times 75 \mathrm{~mm}$ glass tubes. The gels were photopolymerized with riboflavin $\left(4 \mu \mathrm{g} \mathrm{ml}^{-1}\right)$. Protein samples $(50 \mu \mathrm{g}$ in $50 \mu \mathrm{l})$ were applied to the gels as $25 \%$ (w/v) sucrose solutions and overlaid, successively, with $50 \mu 120 \%$ sucrose and $50 \mu 110 \%$ sucrose solutions. The electrolyte solution in the upper chamber was $0.03 \mathrm{M}-\mathrm{H}_{2} \mathrm{SO}_{4}$; in the lower chamber, it was $0.01 \mathrm{M}-$ $\mathrm{Ca}(\mathrm{OH})_{2}$ in $0.04 \mathrm{M}-\mathrm{NaOH}$. The lower chamber was maintained at $4{ }^{\circ} \mathrm{C}$ by cold water circulation. With the anode in the upper chamber, an electric potential of $20 \mathrm{~V} \mathrm{~cm}^{-1}$ of gel was applied for $4 \mathrm{~h}$. Several gels were cut in $5 \mathrm{~mm}$ sections, crushed in $1 \mathrm{ml}$ distilled water and the $\mathrm{pH}$ gradient was determined. The other gels were washed with cold $0 \cdot 1 \mathrm{M}$-sodium bicarbonate buffer $(\mathrm{pH} 10)$ and stained for proteins by the procedure of Otavsky \& Drysdale (1975) or specifically for glycerol dehydrogenase, as described above for polyacrylamide disc gel electrophoresis.

SDS-polyacrylamide gel electrophoresis. The enzyme was denatured with SDS according to the procedure of Fairbanks et al. (1971). The enzyme sample $(500 \mu \mathrm{g})$ was prepared in $1 \mathrm{ml} 0.04 \mathrm{M}$-Tris/acetate buffer (pH 6.4) containing 0.001 $\mathrm{M}$-EDTA, 0.14 $\mathrm{M}$-2-mercaptoethanol and $1 \%$ recrystallized SDS. The sample was then incubated for $12 \mathrm{~h}$ at $37^{\circ} \mathrm{C}$. The marker proteins ribonuclease A, chymotrypsinogen, ovalbumin and bovine serum albumin were treated in a similar way. Tracking dye concentrate containing $0.5 \%(\mathrm{w} / \mathrm{v})$ bromophenol blue and $30 \%$ sucrose was added to the sample to make the protein samples $6 \%$ with respect to sucrose. The $7.5 \%$ gels were prepared in $0.1-\mathrm{M}$ Tris/acetate buffer (pH 6.4) containing $1 \%$ SDS in $5 \times$ $75 \mathrm{~mm}$ glass tubes. The same buffer was used for running the electrophoresis. Approximately $25 \mu \mathrm{g}$ protein was applied to each gel and subjected to electrophoresis at $2.5 \mathrm{~mA}$ per tube for $4.5 \mathrm{~h}$. The gels were fixed in isopropyl alcohol/acetic acid/water (4:1:5, by vol.) for $4 \mathrm{~h}$ and stained for protein in $0 \cdot 25 \%$ Coomassie Brilliant Blue $\mathrm{R}$ in $7 \%$ acetic acid for $4 \mathrm{~h}$. The gels were then destained in a solution containing $7 \cdot 5 \%$ acetic acid and $5 \%$ methanol.

\section{RESULTS}

\section{Enzyme purification}

The results of the purification scheme used for NADP+-linked glycerol dehydrogenase are presented in Table 1 . The crude extract was markedly pigmented and turbid and normally had a specific activity of about 0.041 .

Step 1 -ethodin treatment. Nucleic acids were precipitated from the crude extract by the dropwise addition of a $2 \%$ aqueous solution of ethodin (6,9-diamino-2-ethyoxyacridine lactate) over $30 \mathrm{~min}$, with constant stirring, to a final concentration of $200 \mathrm{mg}$ ethodin $(\mathrm{g} \text { protein })^{-1}$. After $4 \mathrm{~h}$, the yellow precipitate was removed by centrifuging at $20000 \mathrm{~g}$ for $15 \mathrm{~min}$. This step resulted in no loss of enzyme activity and in 2.6-fold purification.

Step 2-ammonium sulphate fractionation. Finely powdered ammonium sulphate was added to the supernatant from the previous step over $30 \mathrm{~min}$ to $55 \%$ saturation. The 
precipitate was removed by centrifugation $(20000 \mathrm{~g}$ for $20 \mathrm{~min}$ ) and discarded, and the supernatant was brought to $75 \%$ saturation by further addition of finely powdered ammonium sulphate. After $2 \mathrm{~h}$ the precipitate was collected by centrifuging at $20000 \mathrm{~g}$ for

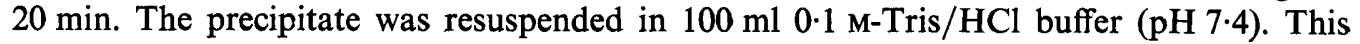
step resulted in the loss of $19 \%$ of enzyme activity but in an overall 5.9-fold purification.

Step 3 -calcium phosphate gel negative absorption. Calcium phosphate gel was added to the enzyme fraction from the previous step at a gel:protein ratio of $3: 1$, and gently stirred for $1 \mathrm{~h}$. The suspension was then centrifuged at $15000 \mathrm{~g}$ for $15 \mathrm{~min}$, and the supernatant was collected. The enzyme was precipitated by the addition of ammonium sulphate to $75 \%$ saturation and collected by centrifugation $(15000 \mathrm{~g}$ for $15 \mathrm{~min})$, dissolved in $20 \mathrm{ml} 0 \cdot 1 \mathrm{M}$ Tris/ $\mathrm{HCl}$ buffer $(\mathrm{pH} \mathrm{7.4)}$ ) and centrifuged at $35000 \mathrm{~g}$ for $30 \mathrm{~min}$ to remove any remaining gel.

Step 4 - Sephadex G-100 gel filtration. A Sephadex G-100 column (Pharmacia K 26/70) with a bed volume of $300 \mathrm{ml}$ was equilibrated by washing with $0.1 \mathrm{M}$-Tris/ $\mathrm{HCl}$ buffer (pH 7.4). The enzyme fraction from the previous step was applied to the column and eluted with $300 \mathrm{ml} 0.1 \mathrm{M}$-Tris $/ \mathrm{HCl}$ buffer ( $\mathrm{pH} \mathrm{7.4)}$ ) at a flow rate of $40 \mathrm{ml} \mathrm{h}^{-1}$. The enzyme frac-

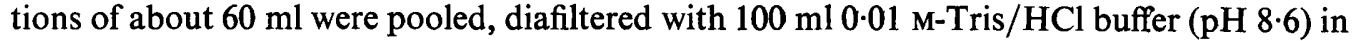
an Amicon ultrafiltration cell with PM-10 filter, and adjusted to $20 \mathrm{ml}$ with similar buffer. This step removed about $45 \%$ of extraneous protein without any significant loss of enzyme activity.

Step 5-DEAE Bio-Gel $A$ ion exchange chromatography. A DEAE Bio-Gel A column (Pharmacia K 26/70) with a bed volume of $250 \mathrm{ml}$ was equilibrated by washing with $0.01 \mathrm{M}$-Tris/ $\mathrm{HCl}$ buffer ( $\mathrm{pH} \mathrm{8.6)}$. The enzyme fraction from the previous step was applied to the column and washed with $200 \mathrm{ml}$ of similar buffer. The enzyme was found to be bound to the gel at this ionic concentration and was eluted in two steps. First, $200 \mathrm{ml} 0.01 \mathrm{M}-$ Tris/ $\mathrm{HCl}$ buffer containing $0.025 \mathrm{M}-\mathrm{KCl}(\mathrm{pH} \mathrm{8.6)}$ was passed through the column. Secondly, the enzyme was eluted with $200 \mathrm{ml} 0.01 \mathrm{M}-\mathrm{Tris} / \mathrm{HCl}$ buffer containing $0.05 \mathrm{M}-\mathrm{KCl}(\mathrm{pH} \mathrm{8.6)}$. The enzyme fractions of about $50 \mathrm{ml}$ were pooled, diafiltered with $100 \mathrm{ml} 0 \cdot 1 \mathrm{M}$-Tris/HCl buffer ( $\mathrm{pH} 7 \cdot 4$ ) in the Amicon ultrafiltration cell, and adjusted to $20 \mathrm{ml}$ with similar buffer. This step resulted in $9 \%$ loss of enzyme activity and in an overall 44-fold purification.

Step 6-Cibacron Blue affinity chromatography. A Cibacron Blue-Sepharose column (Pharmacia K 26/40) with a bed volume of $150 \mathrm{ml}$ was washed and equilibrated with $0 \cdot 1 \mathrm{M}$-Tris/ $\mathrm{HCl}$ buffer $(\mathrm{pH} \mathrm{7.4)}$ ). The enzyme fraction from the previous step was applied to the column and washed with $100 \mathrm{ml}$ of similar buffer. The enzyme was found to be bound to the gel and was eluted in two steps. First, $100 \mathrm{ml} 0.1 \mathrm{M}$-Tris/ $\mathrm{HCl}$ buffer containing $0 \cdot 1 \mathrm{M}-\mathrm{KCl}(\mathrm{pH} \mathrm{7.4)}$ was passed through the column. Secondly, the enzyme was eluted with $100 \mathrm{ml} \mathrm{0} \cdot 1 \mathrm{M}$-Tris/HCl buffer containing $0 \cdot 2 \mathrm{M}-\mathrm{KCl}(\mathrm{pH} \mathrm{7.4)}$. The enzyme fractions of about $50 \mathrm{ml}$ were pooled, diafiltered with $100 \mathrm{ml} \mathrm{0.1} \mathrm{M-Tris/HCl} \mathrm{buffer}(\mathrm{pH} \mathrm{7.4})$ in the Amicon ultrafiltration cell, and adjusted to $14 \mathrm{ml}$ with similar buffer. This step resulted in a specific activity of 20.7 with $54 \%$ yield and an overall 505 -fold purification. This preparation was used for further studies. No significant differences were observed in the specific activities of three repetitive purifications of the enzyme.

\section{Purity of the enzyme}

Polyacrylamide disc gel electrophoresis of purified glycerol dehydrogenase showed a single band after staining for specific enzyme activity (Fig. 1, left gel). No enzymically inactive bands were detected by Coomassie Brilliant Blue $\mathrm{R}$ staining of proteins in parallel gels.

Isoelectric focusing of purified glycerol dehydrogenase in polyacrylamide gels showed five bands after staining for specific enzyme activity (Fig. 1, right gel). No enzymically inactive bands were detected by Coomassie Brilliant Blue $\mathrm{R}$ staining of proteins in parallel gels. 


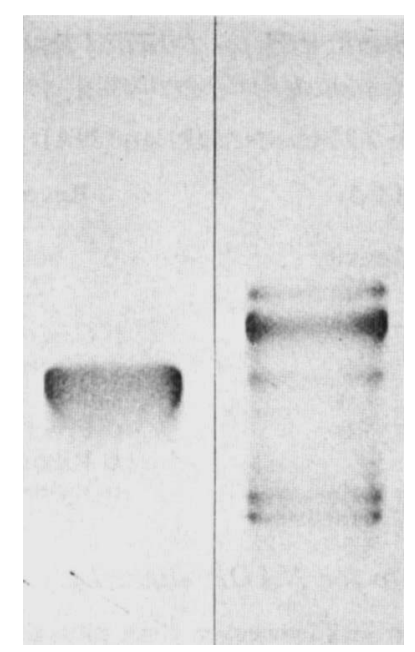

Fig. 1. Specific staining for NADP+-linked glycerol dehydrogenase in polyacrylamide gels. Left gel: single band following disc gel electrophoresis. Right gel: five bands following isoelectric focusing, with pI values (top to bottom) of $3 \cdot 8,4 \cdot 0,4 \cdot 5,5 \cdot 0$ and $5 \cdot 1$.

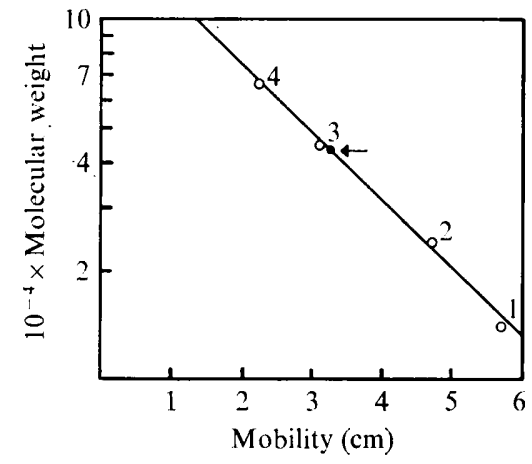

Fig. 2

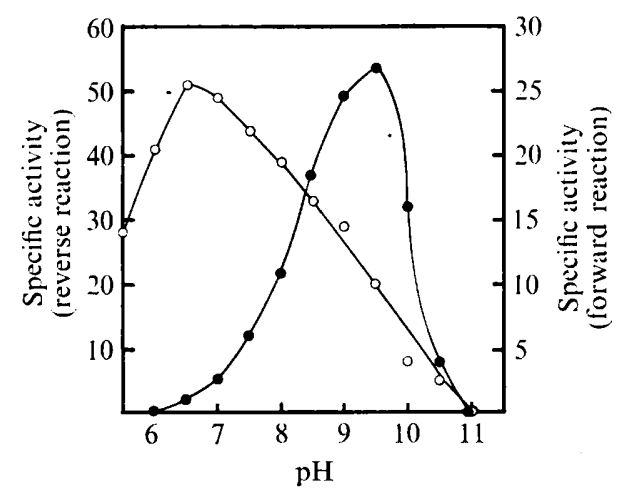

Fig. 3

Fig. 2. Subunit molecular weight determination of NADP ${ }^{+}-$linked glycerol dehydrogenase (arrow) following SDS-polyacrylamide gel electrophoresis. Reference proteins and their molecular weights are: 1 , ribonuclease A, $13700 ; 2$, chymotrypsinogen, $25000 ; 3$, ovalbumin, $45000 ; 4$, bovine serum albumin, 68000.

Fig. 3. Effect of pH on the specific activity of NADP+-linked glycerol dehydrogenase in the forward (glycerol $\rightarrow$ glyceraldehyde, $O$ ) and reverse (glyceraldehyde $\rightarrow$ glycerol, $O$ ) reactions. Determinations were made with substrates at $50 \mathrm{~mm}$, cofactors at $0.25 \mathrm{~mm}$ and $10 \mu 1$ purified enzyme.

\section{Molecular weight}

Subunit molecular weight was estimated by SDS-polyacrylamide gel electrophoresis. A single protein band was found, and a molecular weight of about 43000 was estimated from the standard curve (Fig. 2). A total molecular weight was estimated by gel filtration with Sephadex G-100 and G-200 to be about 160000 .

\section{Effect of $\mathrm{pH}$}

The specfic activity of glycerol dehydrogenase was determined between pH 5.5 and 11 . The oxidation of glycerol to glyceraldehyde was optimal at $\mathrm{pH} 9 \cdot 5$, whereas the reduction of glyceraldehyde to glycerol was optimal at pH 6.5 (Fig. 3). 
Table 2. Substrate specificities for forward and reverse reactions of $N A D P^{+-}$-linked glycerol dehydrogenase at optimum $\mathrm{pH}$ values

Determinations were made with $0.25 \mathrm{mM}-\mathrm{NADP}^{+}$and NADPH and $10 \mu 1$ purified enzyme.

$\begin{array}{lr}\begin{array}{l}\text { Substrate } \\ (100 \mathrm{~mm})\end{array} & \begin{array}{c}\text { Activity } \\ (\%)\end{array} \\ \text { Glycerol } & 100 \\ \text { D-Mannitol } & 0 \\ \text { D-Sorbitol } & 0 \\ \text { Xylitol } & 0\end{array}$

\begin{tabular}{lr}
\multicolumn{1}{c}{$\begin{array}{c}\text { Substrate } \\
(25 \mathrm{~mm})\end{array}$} & $\begin{array}{c}\text { Activity } \\
(\%)\end{array}$ \\
$\begin{array}{lr}\text { D-Glyceraldehyde } \\
\text { L-Glyceraldehyde }\end{array}$ & 100 \\
Dihydroxyacetone & 36 \\
D-Fructose & 43 \\
D-Ribose & 0 \\
D-Xylose & 0 \\
& 0
\end{tabular}

Table 3. Kinetic data for NADP+-linked glycerol dehydrogenase

Kinetic parameters were obtained from Lineweaver-Burk plots at near-saturating concentrations of substrates. Determinations were made with $50 \mathrm{mM}$-CHES buffer (pH 9.5) or $50 \mathrm{~mm}$-MES buffer (pH 6.5) and $10 \mu \mathrm{l}$ purified enzyme.

Reaction
9.5
9.5
6.5
6.5

Substrate

Glycerol

NADP+

D-Glyceraldehyde

NADPH

$K_{\mathrm{m}}(\mathrm{M})$
$1.43 \times 10^{-1}$
$5.60 \times 10^{-5}$
$1.15 \times 10^{-2}$
$2.40 \times 10^{-5}$

\section{Substrate and cofactor specificity}

The forward reaction was specific for glycerol, as no activity was detected with sugar alcohols such as D-mannitol, D-sorbitol or xylitol with $\mathrm{NADP}^{+}$or $\mathrm{NAD}^{+}$as cofactors. The reverse reaction was maximal with $\mathrm{D}$-glyceraldehyde as substrate; with L-glyceraldehyde, a decrease to $36 \%$ of the activity with D-glyceraldehyde was observed, suggesting stereospecificity of the enzyme. Dihydroxyacetone also served as substrate for the reverse reaction, with $43 \%$ of the activity with D-glyceraldehyde. No activity was detected with D-fructose, D-ribose or D-xylose (Table 2). The enzyme reaction had a specific requirement for NADP+ or NADPH as cofactors, since no activity was detected with $\mathrm{NAD}^{+}$or NADH.

\section{Kinetic data}

Kinetic parameters for glycerol dehydrogenase in the oxidative and reductive reactions were determined at the optimum $\mathrm{pH}$ values. Lineweaver-Burk plots were used to calculate the apparent $K_{\mathrm{m}}$ and $V_{\max }$ of each substrate (Table 3). The $K_{\mathrm{m}}$ values obtained for glycerol and D-glyceraldehyde were $1.43 \times 10^{-1} \mathrm{M}$ and $1.15 \times 10^{-2} \mathrm{M}$, respectively. The $K_{\mathrm{m}}$ values for $\mathrm{NADP}^{+}$and NADPH were $5.60 \times 10^{-5} \mathrm{M}$ and $2.40 \times 10^{-5} \mathrm{M}$, respectively.

\section{Stability of the enzyme}

Purified enzyme preparations did not lose activity for at least 3 months when stored at -20 or $4{ }^{\circ} \mathrm{C}$. Enzyme preparations obtained after ammonium sulphate fractionation were stable in the absence of 2-mercaptoethanol. Heat treatments of the enzyme were done with $50 \mu \mathrm{g}$ protein in $1 \mathrm{ml} 0.1 \mathrm{M}$-Tris $/ \mathrm{HCl}$ buffer $(\mathrm{pH} \mathrm{7.4)}$. The enzyme lost $98 \%$ activity at $50^{\circ} \mathrm{C}$ after $5 \mathrm{~min}$. At $45^{\circ} \mathrm{C}$, the half-life of the enzyme was approximately $25 \mathrm{~min}$, whereas addition of $400 \mathrm{~mm}$-glycerol increased the half-life to approximately $45 \mathrm{~min}$.

\section{Miscellaneous properties}

Ammonium ion was reported to activate $\mathrm{NAD}^{+}$-linked glycerol dehydrogenase from bacteria, as well as some NADP+-linked glycerol dehydrogenases (aldose reductases) from 
mammalian tissues (Kormann et al., 1972). Another group of NADP+-linked glycerol dehydrogenases from yeast and lens was activated by sulphate ions (Sheys \& Doughty, $1971 b$ ). In the present study the effect of $\mathrm{NH}_{4} \mathrm{Cl}$ and $\mathrm{Na}_{2} \mathrm{SO}_{4}$ on enzyme activity was determined at various concentrations. Ammonium ion had no effect on enzyme activity at 5 to $20 \mathrm{~mm}$. Similarly, sulphate ion had little effect on enzyme activity at $10 \mathrm{~mm}$ and reduced activity to $83 \%$ at $20 \mathrm{~mm}$. No metal ion requirements for enzyme activity were detected. In the presence of 5 and $10 \mathrm{~mm}$-EDTA, respectively, 90 and $80 \%$ of the enzyme activity remained. $p$-Hydroxymercuribenzoate at $1 \mathrm{mM}$ inhibited $50 \%$ of the enzyme activity and at $2 \mathrm{mM}, 100 \%$.

\section{DISCUSSION}

The molecular weights of NADP+-linked glycerol dehydrogenase from different sources vary considerably. The total molecular weight of the enzyme from rabbit skeletal muscle was estimated to be 34000 (Kormann et al., 1972) and from the alga Dunaliella, 65000 (Ben-Amotz \& Avron, 1974). The enzyme from Rhodotorula was reported to have a total molecular weight of 61000 with two subunits of 38000 and 23000 ; moreover, the 38000 molecular weight species had enzyme activity, whereas the smaller species was inactive (Sheys \& Doughty, 1971 a). The enzyme from Mucor was reported to have a total molecular weight of about 100000 with a subunit molecular weight of 28000 (Dutler et al., 1977). The enzyme from Neurospora in the present study was estimated by gel filtration to have a total molecular weight of about 160000 and, by SDS-polyacrylamide gel electrophoresis, to have a subunit molecular weight of about 43000 .

The purified glycerol dehydrogenase from Neurospora, upon polyacrylamide disc gel electrophoresis, migrated as a single protein band. However, when the enzyme preparation was subjected to isoelectric focusing in polyacrylamide gels with ampholytes in the $\mathrm{pH}$ range 3 to 10 , five protein bands were revealed, all of which showed specific enzyme activity. The existence of several active species of enzyme with pI values ranging from $3 \cdot 8$ to $5 \cdot 1$ suggested the presence of multimeric forms, possibly isozymes.

The optimum $\mathrm{pH}$ for the forward reaction was 9.5 and for the reverse reaction, 6.5 . Similar $\mathrm{pH}$ profiles were reported for glycerol dehydrogenase from rat skeletal muscle (Toews, 1966), Dunaliella (Ben-Amotz \& Avron, 1973, 1974) and Mucor (Dutler et al., 1977).

Our studies on substrate specificities of glycerol dehydrogenase from Neurospora showed that this enzyme had an absolute requirement for $\mathrm{NADP}^{+}$or NADPH as cofactors, since $\mathrm{NAD}^{+}$or NADH could not be substituted. It was also apparent from the results that D-glyceraldehyde was the preferred substrate for the enzyme, since the activity with Lglyceraldehyde was reduced to $36 \%$ of that with D-glyceraldehyde. Similar properties were reported for the enzyme from rat skeletal muscle (Kormann et al., 1972). The enzyme from Neurospora had activity with dihydroxyacetone reduced to $43 \%$ of that with D-glyceraldehyde, whereas Kormann et al. (1972) reported reduction to $4 \%$ for the enzyme from rabbit skeletal muscle. In Dunaliella (Ben-Amotz \& Avron, 1973), dihydroxyacetone was the preferred substrate, and less than $5 \%$ relative activity was found with DL-glyceraldehyde. In Mucor (Hochuli et al., 1977) dihydroxyacetone was the preferred substrate, and 0.3 and $6.1 \%$ relative activity, respectively, was found with D- and L-glyceraldehyde. In contrast, NAD ${ }^{+}$-linked glycerol dehydrogenase from Aerobacter had 5.4 and 52.8\% activity, respectively, with $\mathrm{D}$ - and L-glyceraldehyde compared to that with dihydroxyacetone (Hochuli et al., 1977).

At substrate concentrations of less than $100 \mathrm{~mm}$, glyceraldehyde reduction proceeded at twice the rate of glycerol oxidation in the present study. This was also evident from the Michaelis constants for glycerol $\left(1.43 \times 10^{-1} \mathrm{M}\right)$ and D-glyceraldehyde $\left(1.15 \times 10^{-2} \mathrm{M}\right)$ determined at the optimum $\mathrm{pH}$ values of the forward and reverse reactions, respectively. For a similar enzyme from Rhodotorula, $K_{\mathrm{m}}$ values of $4.5 \times 10^{-3} \mathrm{M}$ for glycerol and $9 \times 10^{-4} \mathrm{M}$ 
for D-glyceraldehyde were reported (Sheys et al., 1971; Sheys \& Doughty, 1971b). Kormann et al. (1972) reported a $K_{\mathrm{m}}$ value of $1 \cdot 5 \times 10^{-4} \mathrm{M}$ for D-glyceraldehyde, using glycerol dehydrogenase from rabbit skeletal muscle. The $K_{\mathrm{m}}$ values for $\mathrm{NADP}^{+}$and NADPH were $5.60 \times 10^{-5} \mathrm{M}$ and $2.40 \times 10^{-5} \mathrm{M}$, respectively, with the enzyme from Neurospora. Although the observed $K_{\mathrm{m}}$ values for glycerol dehydrogenase from different organisms vary, the enzyme was found to have higher affinity for D-glyceraldehyde and NADPH than for glycerol and NADP+.

Purified glycerol dehydrogenase from Neurospora showed no detectable activity with the following sugar alcohols (polyols) and sugars: D-mannitol, D-sorbitol, xylitol, D-fructose, D-ribose or D-xylose. We detected high levels of NADP+-linked dehydrogenase activity for each of these substrates with crude enzyme preparations from Neurospora. Our results suggest that the NADP+-linked glycerol dehydrogenase was distinct from polyol dehydrogenase.

M.V-R. was the recipient of a University of Georgia Postdoctoral Fellowship.

\section{REFERENCES}

Ben-Amotz, A. \& Avron, M. (1973). NADP specific dihydroxyacetone reductase from Dunaliella parva. FEBS Letters 29, 153-155.

Ben-Amotz, A. \& Avron, M. (1974). Isolation, characterization, and partial purification of a reduced nicotinamide adenine dinucleotide phosphate-dependent dihydroxyacetone reductase from the halophilic alga Dunaliella parva. Plant Physiology 53, 628-631.

Bergmeyer, H. U. (1974). Procedures related to enzymatic analysis. In Methods of Enzymatic Analysis, pp. 171-176. Edited by H. U. Bergmeyer. New York: Academic Press.

BöHME, H.-J., KoPPERSCHLÄGER, G., Schulz, J. \& HoFMANN, E. (1972). Affinity chromatography of phosphofructokinase using Cibacron blue F3G-A. Journal of Chromatography 69, 209-214.

Bosron, W. F. \& PraIrIE, R. L. (1972). Triphosphopyridine nucleotide-linked aldehyde reductase. $\mathrm{I}$. Purification and properties of the enzyme from pig kidney cortex. Journal of Biological Chemistry 247, 4480-4485.

Davis, B. J. (1964). Disc electrophoresis. II. Method and applications to human serum proteins. Annals of the New York Academy of Sciences 121, 404 427.

Dutler, H., VAN der BaAN, J. L., Hochuli, E., KIS, Z., Taylor, K. E. \& Prelog, V. (1977). Dihydroxyacetone reductase from Mucor javanicus. I. Isolation and properties. European Journal of Biochemistry 75, 423-432.

Fairbanks, G., Steck, T. L. \& Wallach, D. F. H. (1971). Electrophoretic analysis of the major polypeptides of the human erythrocyte membrane. Biochemistry 10, 2606-2617.

Good, N. E., Winget, G. D., Winter, W., ConNally, T. N., IzaWa, S. \& Singh, R. M. M. (1966). Hydrogen ion buffers for biological research. Biochemistry 5, 467-477.

Hochuli, E., TAylor, K. E. \& Dutler, H. (1977). Dihydroxyacetone reductase from Mucor javanicus. 2. Identification of the physiological substrate and reactivity towards related compounds. European Journal of Biochemistry 75, 433-439.

Keilin, D. \& Hartree, E. F. (1938). On the mechanism of the decomposition of hydrogen peroxide by catalase. Proceedings of the Royal Society B124, 397-405.

Kormann, A. W., Hurst, R. O. \& Flynn, T. G. (1972). Purification and properties of an NADP+. dependent glycerol dehydrogenase from rabbit skeletal muscle. Biochimica et biophysica acta 258, 40-55.

LIN, E. C. C. (1976). Glycerol dissimilation and its regulation in bacteria. Annual Review of Microbiology 30, 535-578.

Otavsky, W. I. \& DRYsdale, J. W. (1975). Recent staining artifacts with LKB 'ampholines' on gel isoelectric-focusing. Analytical Biochemistry 65, 533-536.

Sheys, G. H., ARnold, W. J., WATSON, J. A., HaYashi, J. A. \& Doughty, C. C. (1971). Aldose reductase from Rhodotcrula. I. Purification and properties. Journal of Biological Chemistry 246, 3824-3827.

Sheys, G. H. \& Doughty, C. C. (1971 a). Subunits of aldose reductase from Rhodotorula. Biochimica et biophysica acta 235, 414-417.

Sheys, G. H. \& Doughty, C. C. $(1971 b)$. The reaction mechanism of aldose reductase from Rhodotorula. Biochimica et biophysica acta 242, 523-531.

ToEws, C. J. (1966). Evidence for the metabolism of glycerol by skeletal muscle and presence of a muscle nicotinamide-adenine dinucleotide phosphate-dependent glycerol dehydrogenase. Biochemical Journal 98, 27c-29c.

ToEws, C. J. (1967). The kinetics and reaction mechanism of the nicotinamide-adenine dinucleotide phosphate-specific glycerol dehydrogenase of rat skeletal muscle. Biochemical Journal 105, 1067-1073.

Viswanath-Reddy, M., Bennett, S. N. \& Howe, H. B. (1977). Characterization of glycerol nonutilizing and protoperithecial mutants of Neurospora. Molecular and General Genetics 153, 29-38.

WestergaARD, M. \& Mitchell, H. K. (1947). Neurospora. V. A synthetic medium favouring sexual reproduction. American Journal of Botany 34, 573-577. 